\title{
Delimitation of the Alcantarea extensa complex (Bromeliaceae) and a new species from Espírito Santo, Brazil
}

\author{
Delimitação do complexo Alcantarea extensa (Bromeliaceae) \\ e uma nova espécie do Espírito Santo, Brasil
}

Leonardo M. Versieux ${ }^{1}$ \& Maria das Graças Lapa Wanderley ${ }^{2}$

\begin{abstract}
The species complex related to Alcantarea extensa is presented and delimited as: A. extensa, A. vinicolor, A. burle-marxii, A. turgida, A. distractila, A. lurida, A. simplicisticha, A. nigripetala, A. mucilaginosa, and A. trepida. Alcantarea trepida, known from Espírito Santo state, southeastern Brazil, is described as new, and illustrated. It is compared to $A$. extensa, A. simplicisticha, and $A$. vinicolor from which it differs by the robust, erect, compound inflorescence with more numerous flowers and by the straight and thicker rachilla.

Key words: Atlantic Rainforest, endemism, inselberg, species complex, Tillandsioideae.

\section{Resumo}

O complexo de espécies relacionadas a Alcantarea extensa é apresentado e delimitado como: A. extensa, $A$. vinicolor, A. burle-marxii, A. turgida, A. distractila, A. lurida, A. simplicisticha, A. nigripetala, A. mucilaginosa e $A$. trepida. Alcantarea trepida, conhecida do estado do Espírito Santo, é descrita como nova e ilustrada. É comparada com A. extensa, A. simplicisticha e A. vinicolor, das quais difere pela inflorescência ereta e robusta com flores mais numerosas e pelas ráquilas retas e mais grossas.

Palavras-chave: Mata Atlântica, afloramento rochoso, endemismo, complexo de espécies, Tillandsioideae.
\end{abstract}

\section{Introduction}

Alcantarea (E. Morren ex Mez) Harms, Bromeliaceae, Tillandsioideae, with near 23 rupicolous species is a genus endemic to eastern Brazil, occurring on inselbergs within the Atlantic Rainforest in the States of Bahia, Minas Gerais, Espírito Santo, Rio de Janeiro e São Paulo as well as in open grassland outcrops in campo rupestre vegetation at Bahia and Minas Gerais (Versieux \& Wanderley 2007a).

The importance of inselbergs as sites for rupicolous Bromeliaceae populations differentiation, particularly Alcantarea, has been demonstrated in a recent series of papers (Barbará et al. 2007, 2008, 2009). As inland islands, these rock outcrops, isolated from each other, may contribute to high genetic distance within populations of the same species. Speciation or population partitioning within the same species are the evolutionary consequences of the fragmented distribution and low level of genetic exchange (Barbará et al. 2007).

Versieux \& Wendt (2006) noted that Alcantarea extensa should be treated as complex of species, due to the wide variation observed in the herbarium material, particularly in rosette and inflorescence size and colors of bracts and floral parts. The present paper aims to discuss the taxonomic problems and to delimit the complex of species related to A. extensa, and to describe one new taxon.

\section{Results and Discussion}

For several decades, species now belonging to the genus Alcantarea, then classified under Vriesea subg. Alcantarea, were poorly understood taxonomically. This situation, for this horticultural and ecologically important genus, could be partially

\footnotetext{
${ }^{1}$ Universidade Federal do Rio Grande do Norte, Depto. Botânica, Ecologia e Zoologia, 59072-970, Natal, RN, Brazil. Author for correspondence: lversieux@yahoo.com.br ${ }^{2}$ Instituto de Botânica, C.P. 3005, São Paulo, SP, 01061-970, Brazil.
} 
explained by the lack of well-collected herbarium specimens and also by a fragmentary knowledge of the living plants in the field. Possibly the large dimensions of leaves and inflorescences, together with the difficulties accessing the habitat, sometimes demanding rock climbing techniques, and the blooming period concentrated during the rainy season, explain why it remains so poorly represented in the scientific collections. More recently, several new species have been described coming from areas that were poorly botanized and also due to the better comprehension of the limits of polyphyletic taxa. Observation of living plants during field work followed by cultivation in greenhouse are now considered key points for better delimiting the species and also to understand morphological features that are difficult to examine (e.g. floral characters) on dried specimens. Employing such procedures during the revision of the genus we were able to delimit a group of taxa, which will be called the "Alcantarea extensa complex" that is described below.

\section{The Alcantarea extensa complex}

Vriesea extensa $(=$ Alcantarea extensa $(\mathrm{L}$. B. Sm.) J. R. Grant) was described by Smith (1943), from a plant collected in fruit at Cachoeiro do Itapemirim, pico de Itabira, Espírito Santo, and was characterized by its long inflorescence branches and floral bracts showing a protuberance near the apex (gibbous). In the original description, Smith (1943) put under synonym Vriesea regina sensu Wittmack (1891) and discussed that Wittmack's description was based on a plant from Serra do Picú (presently known as Serra de Itatiaia), 1600 ms.m, on the border of Minas Gerais and Rio de Janeiro States. While checking the protologues we noticed that Smith (1943) probably misunderstood Wittmack's description, which says that his plants were grown from seeds collected at Rio Doce, and also mentions the presence of mucilage in the flowers and that the petals have raw meat color and presents illustrations and measures that clearly indicate that the plant he had in hands was, in fact, very close to $A$. extensa. This information is important to clarify the actual range of the species, since A. extensa grows on the southern portion of Espírito Santo, eastern Minas Gerais, and there is only one record for Northern Rio de Janeiro, but there is no occurrence for the Itatiaia range (Serra do Picú) region. After that, Pereira \& Reitz (in Pereira 1974) described Vriesea vinicolor (=A. vinicolor
(E. Pereira \& Reitz) J. R. Grant) from Vargem Alta, Espírito Santo State as well. According to these authors $V$. vinicolor could be differentiated from $V$. extensa by the not gibbous floral bracts shorter than the sepals and also by the stamens equaling the length of the petals. Pereira \& Reitz (in Pereira 1974) also emphasizes that the wine-red leaves of $V$. vinicolor were another distinct feature. Versieux $\&$ Wendt (2006) were the first to recognize that $A$. extensa should be treated as complex of species, due to the high variation observed among the herbarium material, particularly in rosette and inflorescence size, and colors of bracts and floral parts. Versieux \& Wanderley (2007b) described $A$. turgida Versieux \& Wand., from Serra do Cipó, Minas Gerais, which is closely related to Alcantarea extensa and $A$. vinicolor but differs by the pale yellow petals, inflorescence shape (tending to be more bilaterally symmetric and pyramidal), shorter inflorescence branches, by the lustrous green leaves without any trace of epicuticular wax, and by the distinct habitat (campo rupestre) and far inland distribution. Leme \& Paula (2008) described A. distractila Leme \& Paula from Ouro Verde de Minas, eastern Minas Gerais State, as a very closely related taxon to $A$. extensa, but showing shorter leaves, longer branches with more widely spaced and larger flowers. The same authors also described A. lurida Leme collected between Coronel Fabriciano and Braúnas (Leme \& Paula 2008), central-eastern Minas Gerais, and it was compared to A. extensa, however presenting red peduncle and rachis, shorter branches and longer flowers with pale yellow petals. Leme et al. (2008) described two other species of Alcantarea that can also be included in the complex: A. simplicisticha Leme \& A. P. Fontana from Águia Branca, Espírito Santo, with simple inflorescence and A. nigripetala Leme \& L. Kollmann, from Nova Belém, Minas Gerais, which supposedly has black petals. Leme (2009) described A. mucilaginosa Leme, from a cultivated plant collected at Conceição do Castelo, which was also considered to be closely related to A. extensa, differing basically by a larger amount of wax over the leaves and bracts and shorter flowering branches, besides a copious mucilage production. All the above mentioned taxa (A. extensa, A. vinicolor, A. turgida, A. distractila, A. lurida, A. simplicisticha, A. nigripetala, A. mucilaginosa, and A. trepida), together with A. burle-marxii (Leme) J. R. Grant, which occurs in Northeastern Minas Gerais, ca. 450 $\mathrm{km}$ far away from the core area of Alcantarea 
extensa occurrence, can be considered part of the Alcantarea extensa complex. As general features, these taxa present spreading, i.e. radially disposed stamens at anthesis, have petal colors that fade from a darker while in bud to a pale color when petals are fully expanded, most species present yellow wine-red spotted petals, resembling almost orange or sometimes wine-orange, and also there can be differences between the abaxial (darker) and adaxial (paler) petal faces. The floral bracts tend to be more coriaceous and dilated along the central portion and thinner and yellowish along the margins in sicco, petals tend to be more loosely arranged during anthesis and not so spirally recoiled as in other species of the genus, the compound inflorescences frequently are asymmetrical, with different sizes of branches, the primary bracts are always shorter then the lateral peduncles and branches are more laxly distributed.

It's worthy mentioning that Vriesea alta (Baker) E. Morren ex Mez, an old name typified by one of Edouard Morrens' watercolors housed at Kew (Fig. 1), and that was considered to belong to Vriesea subg. Alcantarea by Smith \& Downs (1977), also shows some of the features attributed above to the A. extensa complex. Nevertheless, it is a doubtful taxon, excluded from Alcantarea by Grant (1995) and presumably collected at Panamá, Chiriquí, which bloomed under cultivation in Europe, without any recent collected specimens deposited in herbaria.

According to our ongoing research on the molecular phylogeny of the genus (Versieux et al. unpub. data) the Alcantarea extensa and related taxa appear in a more recently divergent position when compared to the other Alcantarea species. If we consider this group as a recently divergent taxon that has not had the necessary time to accumulate differences, reproductive isolation, and fixed apomorphies it would be easier to understand why species boundaries are so hard to define. An analysis employing 20 microsatellite loci data (Versieux et al. unpub. data) indicates that at least two major groups of $A$. extensa or $A$. aff. extensa with biogeographic correlation exist: one comprising the populations at eastern side of the Mantiqueira range and southern Espírito Santo State that are closely related to A. vinicolor and to A. trepida. And the second clearly distinct group connects populations from Minas Gerais State, distributed mostly on the western side of the Mantiqueira range, along the Rio Doce river basin. As a matter of fact the populations from Espírito Santo tend to show leaves usually bluish green, covered by a thick layer of epicuticular wax, a character already
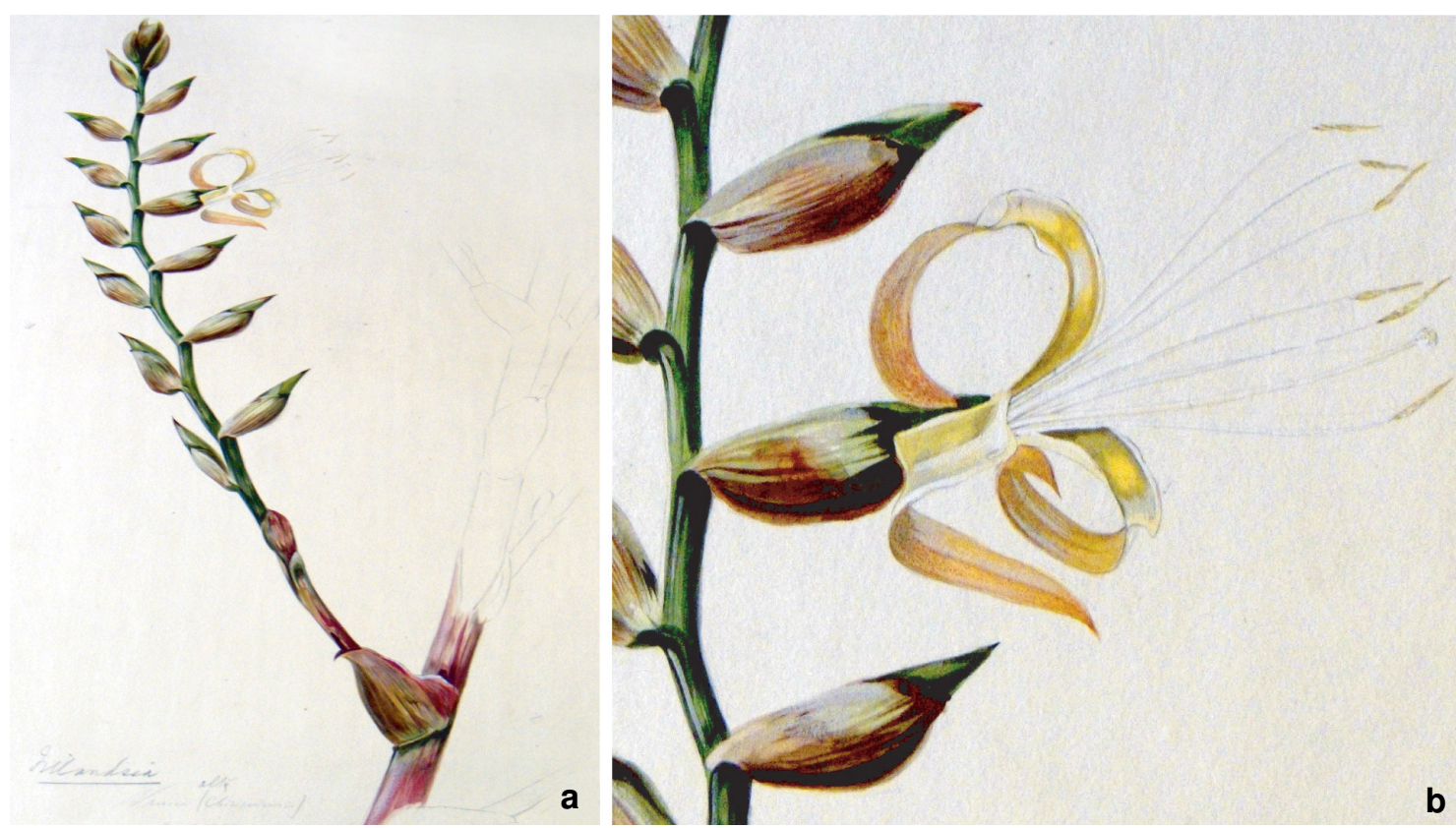

Figure 1 - Vriesea alta (Baker) E. Morren ex. Mez - a. Edourard Morren's Icon housed at Kew, lectotype selected by Smith \& Downs (1977). b. flower detail. (Photos: Lynn Parker). 
mentioned on the type material of $A$. extensa. On the other hand, plants from Minas Gerais are usually smaller in size and have shorter and lustrous leaves, like A. distractila. The population from Carangola, shows petals with slightly convolute praefloration, a very distinct feature for the genus.

Nevertheless better delimitations for the taxa that are involved in this complex, whatever taxonomic status is attributed to them, is difficult due to a great homogeneity in floral characters and an overall resemble that makes indistinguishable sterile plants or incompletely prepared herbaria material (i.e. lacking complete inflorescence or data referring to the number, position, size and arrangement of the branches). The traditionally used character of simple versus compound inflorescences is variable even within the same species as is illustrated here by $A$. trepida, and a closer look beneath the distal peduncle bracts of an unbranched inflorescence may show atrophied ramifications. Variations in inflorescence branch number, amount of wax along the leaves and bracts, leaf and bract color variation between green and red-wine, and amount of mucilage are just general trends to segregate populations. These characters are highly influenced by environmental conditions, especially if under cultivation, and their utility to separate or describe new species is questionable. Thus we suggest more profound analyses for the Alcantarea extensa complex, using additional tools as molecular data, leaf anatomy, and pollen morphology and that new species in this taxonomically complicated group should be based on a population approach, and not relying solely on a single extreme and variant cultivated individual.

Alcantarea trepida Versieux \& Wand. sp. nov.

Figs. 2 a-1, 3 a-i

Type: BRASIL. ESPÍRITO SANTO: Baixo Guandu, inselberg em pastagem, 19²9'26.8'S 4050'37.4'W, 592 m, 27.I.2007, fl., L.M. Versieux \& A.M. Calvente 396 (holotypus: SP; isotypus: RB).

Species nova Alcantareae extensae (L.B. Sm.) J.R. Grant, Alcantareae simplicistichae Leme \& A.P. Fontana et Alcantareae vinicolori (E. Pereira \& Reitz) J.R. Grant floribus luteo-vinosis et staminibus polystichis affinis sed ramis inflorescentiarum longioribus (ad usque $110 \mathrm{~cm}$ longis vs. ad usque $70 \mathrm{~cm}$ longis), erectis, rhachillis crassioribus et rectis (vs. rhachillis flexuosis vel geniculatis) differt.

Rupicolous, flowering (1.5-)2-4 m high, propagating by basal shoots, stem developed, sometimes sprawling. Rosette $0.7-0.9 \times 0.6-1.4 \mathrm{~m}$, infundibuliform, phytotelm developed. Leaves numerous, suberect to erect, marcescent. Leaf sheath $18-30 \times 12-20 \mathrm{~cm}$, ovate to oblong-elliptic, pale to dark castaneous abaxially, pale brown adaxially in sicco, whitish green in vivo, densely lepidote on both surfaces, coriaceous; margins membranaceous, wine-red to wine-red hyaline. Blades 40-68 ×8-11 $\mathrm{cm}$, ligulate, concolorous green, lustrous, with or without wine-red spots abaxially or only toward the apex adaxially, subdensely lepidote abaxially, glabrous to sparsely lepidote toward the apex adaxially, straight to weakly arcuate, coriaceous, distinctly nerved, margins with a narrow $(<1 \mathrm{~mm})$ wine-red edge; blade apex acute, acuminate, winered or green, generally straight, rarely curved, twisted or bent downwards. Peduncle $90-110 \times 2-3 \mathrm{~cm}$, erect, straight, stout, cylindrical to weakly sulcate, concolorous green to green underneath the bracts and wine-red on the sun exposed areas, glabrous, distinctly nerved; internodes $3.5-7 \mathrm{~cm}$ long; bracts of the peduncle: the proximal ones: subfoliaceous and erect; the middle and distal ones: $4.5-10 \times 3-7 \mathrm{~cm}$, triangular passing to ovate, apex acute, attenuate (on the proximal ones) to acuminate (on the distal ones), green to totally pale or dark wine-red, covered by white epicuticular wax on both surfaces, sparsely-lepidote at the base to densely lepidote toward the apex abaxially, densely to sparsely lepidote toward the apex adaxially, suberect-patent to curved, inflated and holding water at the base, distinctly nerved, coriaceous; margins winered. Inflorescence $0.6-0.9 \times 0.3-0.5 \mathrm{~m}$, compound, panicle of spikes, rarely spike, in this case up to $1.1 \mathrm{~m}$ long, ca. $11 \mathrm{~cm}$ wide (excl. the petals), ovoid to ellipsoidal, erect, rachis internodes 2-7 cm long; primary bract (2-)5-8 $\times 4-6 \mathrm{~cm}$, ovate to broadly ovate, apex acuminate, inconspicuously mucronate for ca. $3 \mathrm{~mm}$, with the same coloration as the peduncle bracts, dark castaneous at the center and bordered by yellowish pale castaneous in sicco, glabrescent abaxially, densely lepidote at the base adaxially, involute, suberect, shorter than the base of the lateral peduncle, distinctly nerved, coriaceous, with membranaceous dark castaneous margins (ca. $1 \mathrm{~mm}$ wide). Inflorescence branches (1-)4-9, (11-)18-56(-70) flowered, erect to suberect at anthesis and remaining so after fructification; lateral peduncles (9-)13-16×1-1.2 cm, cylindrical or nearly so, green to reddish green at the exposed portions, glabrous; sterile bracts 3 or 4 , orbicular to broadly elliptic, apex obtuse, weakly uncinate, 3.8-4.4(-5) ×3.2-4.1 cm, wine-reddish castaneous, waxy, glabrous abaxially, subdensely lepidote adaxially, suberect, overlapping each other 


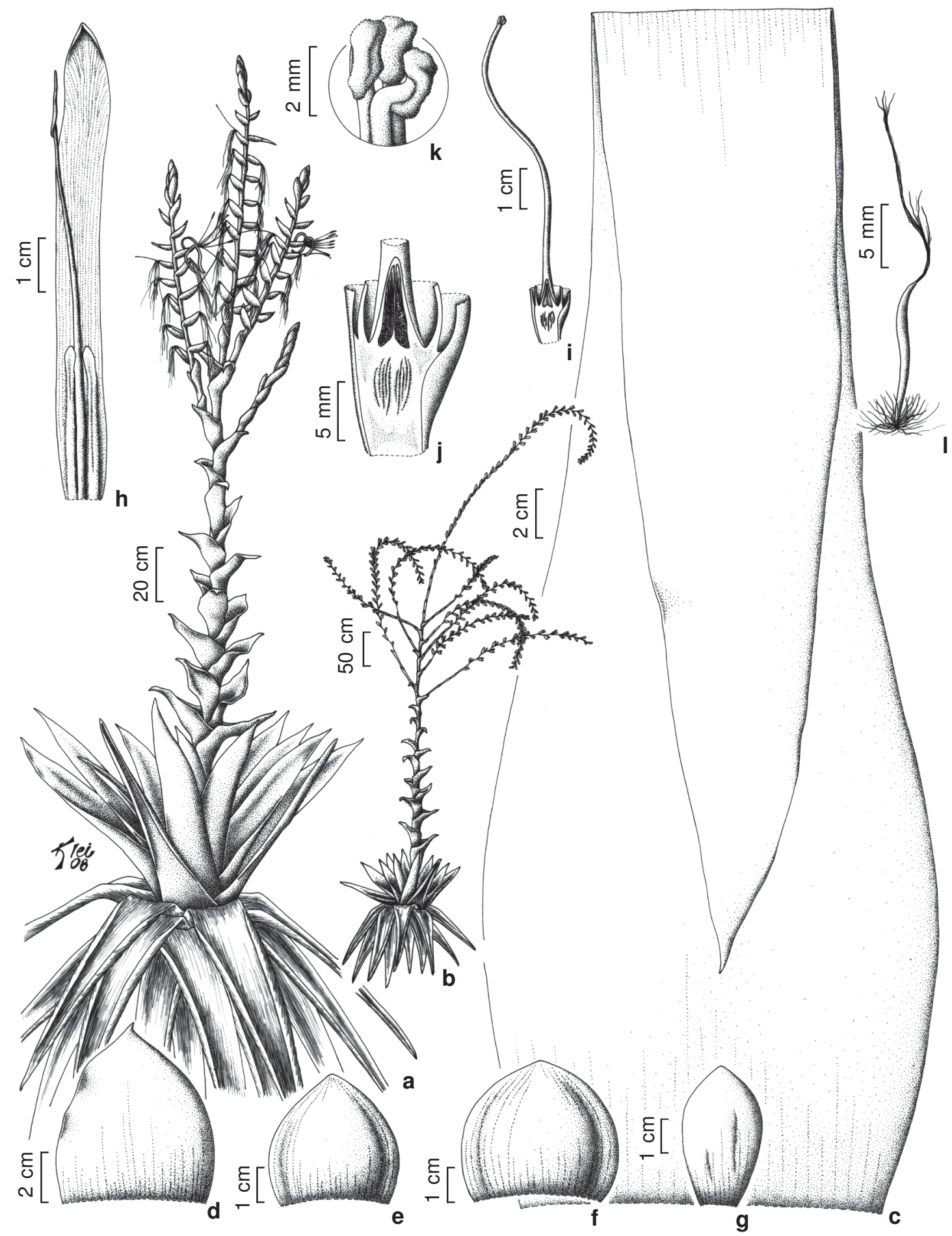

Figure 2 - Alcantarea trepida - a. habit at anthesis; b. habit at fructification; c. leaf; d. peduncle bract; e. primary bract; f. floral bract; g. sepal; h. petal; i. pistil; j. ovary; k. stigma; 1. seed. (a, c-j Versieux 396; b, 1 Versieux 394). 

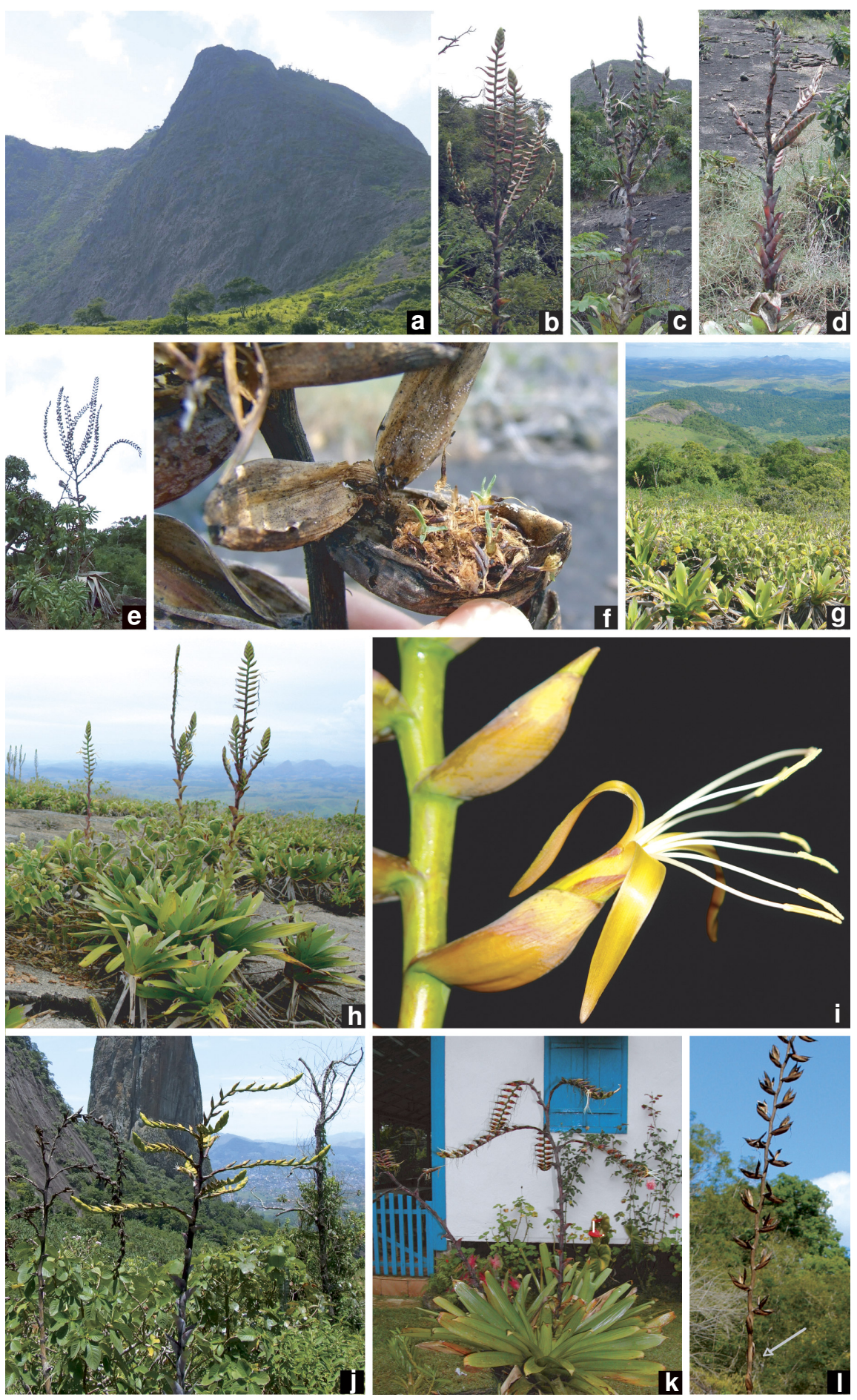

Figure 3 a-l-a-i. Alcantarea trepida - a. habitat at Baixo Guandu; b-d. variation in inflorescence size; e. dead individual with opened capsules and upright branches; f. seeds germinating inside the capsule; g. population at Nova Venécia; h. flowering individuals with both compound and simple inflorescences; i. detail of flower at anthesis. j. Alcantarea extensa at Cachoeiro do Itapemirim, pico de Itabira (type locality), showing patent flowering branches. k. Alcantarea vinicolor under cultivation, showing arcuate branches. 1. Alcantarea simplicisticha, detail of the base of an old fruiting spike where the flexuous rachilla and the erect and short peduncle bracts can be seen (arrow). (a-g Versieux 394, 395, 396; h-i Fraga 1920, j Versieux 380, k Versieux 384.1 cultivated at the Jardim Botânico do Rio de Janeiro. Photos: L.M. Versieux except f: A. Calvente and g-i, 1: C.N. Fraga). 
at least close to the apex, distinctly nerved, the central portion thicker and rugose, ecarinate but sometimes with a protuberance near the apex, coriaceous; margins membranaceous, yellowishhyaline in sicco; rachilla (13-)40-70(-110) cm, straight, rarely weakly geniculate toward the distal portion, green, glabrous; internodes (1.3-)2.5-5 $(-6) \times 1-1.3(-1.6) \mathrm{cm}$, almost quadrangular in cross section; floral bract 3.8-4.8 $\times 3.8-5.5 \mathrm{~cm}$, orbicular to broadly ovate, apex obtuse, weakly uncinate, green bordered by wine-red to completely brownish wine-red or pale brown at the central portion and bordered by a yellowish hyaline stripe (ca. $7 \mathrm{~mm}$ wide) in vivo, glabrous abaxially, subdensely brown lepidote adaxially, completely enfolding the calyx, suberect to patent, distinctly rugose on the central portion, finely nerved along the margins, coriaceous, ecarinate; margins membranaceous, with a narrow $(<1 \mathrm{~mm}$ wide) wine-red line in vivo, yellowish-hyaline in sicco. Flowers not fragrant, distichous; sepals ca. $4 \times 2.3 \mathrm{~cm}$, broadly elliptic to oboelliptic, apex obtuse, symmetric, equaling or exceeding the floral bracts by ca. $5 \mathrm{~mm}$, green to yellowish green with wine-red apex, glabrous to sparsely lepidote toward the apex abaxially, densely brown-lepidote adaxially, chartaceous, ecarinate; margins membranaceous, yellowish-hyaline in sicco; petals $8.7-9.7 \times 1 \mathrm{~cm}$, ligulate, apex obtuse, constricted by the sepals, yellow adaxially, yellow dotted with wine-red abaxially, strongly recurved at anthesis and wilting from the margins to the center without spiraling; petal appendages ca. $32 \times$ $2 \mathrm{~mm}, 2$, ligulate, longitudinally adnate to the petal for ca. $25 \mathrm{~mm}$, apex obtuse; stamens polystichous; filament $70-95 \times 1.5 \mathrm{~mm}$, weakly flattened at the base to cylindrical, white; anther linear, ca. $15 \times 1 \mathrm{~mm}$, yellow, dorsifixed near the base; style $80-90 \times 2 \mathrm{~mm}$, cylindrical to weakly angular, white; stigma lobes ca. $3 \times 1 \mathrm{~mm}$, suberect to patent, white; ovary ca. 9 (superior portion) $\times 5 \mathrm{~mm}$, narrowly ovate, whitish green to white, hypanthium ca. $9 \mathrm{~mm}$; ovules numerous, ca. $0.6 \mathrm{~mm}$. Capsule 4-5×1 cm, narrowlyelliptic, apex acute, brown; seed ca. $5 \times 1 \mathrm{~mm}$, fusiform, brown; basal coma ca. $6 \mathrm{~mm}$, ferruginous; apical coma ca. $14 \mathrm{~mm}$, ferruginous.

The new species described here can be separated from its congeners by a combination of characters such as the distal peduncle bract size and shape, length and position of the inflorescence branches, which have a thick almost quadrangular sided and completely straight rachis. All individuals showing compound inflorescence present their flowering branches upright and close to each other, remaining upright through fructification. Also, $A$. trepida presents the largest number of flowers per branch ever reported for the genus, with up to 70, and its flowering individuals tend to be taller. The closest relatives of this new species probably are A. extensa, A. simplicisticha and $A$. vinicolor all related to each other and belonging to a very homogenous group of species designated here as the $A$. extensa complex, for which many morphological features overlap (Table 1), what may indicate a recent radiation for these taxa. However its densely arranged and long flowering branches that remain in upright position even after the anthesis distinguish this new species from all its congeners. Also, the rachillas are straight and relatively thick. In A. extensa and A. vinicolor inflorescences present patent to arcuate branches (Fig. 3j-k) that are more laxly disposed along the axis, in A. simplicisticha (Fig. 31) the inflorescence is always simple, suberect-arcuate, and all of them have flexuous to geniculate rachillas. The presence of developed stem is another distinct feature of the new taxon. This stem can be erect and hidden by the old marcescent leaves or be sprawling and longer (Fig. 3h). Other differences among these taxa are summarized in the Table 1.

Within the type locality region, $A$. trepida is sympatric with $A$. roberto-kautskyi, a very distinct species but also presenting erect flowering branches, developed stems, floral bracts and buds densely disposed at the apex of the branches and waxy leaves and bracts. A good hypothesis to be tested in a broad population genetic analysis including both species is to check if in the past $A$. trepida received any genetic contribution from $A$. robertokautskyi trough hybridization processes. Low levels of interspecific gene flow for sympatric Alcantarea species have been reported for A. imperialis and $A$. geniculata based on population genetic analysis using microsatellite markers (Barbará et al. 2007; 2009). It would be desirable that such kind of analysis, with an extended sampling of the $A$. extensa complex, could be carried out, providing interesting new data on the genetic cohesiveness of these taxa and populations. Nevertheless, the two species treated here are very divergent, $A$. roberto-kautskyi has many more leaves more densely arranged, white petals, the inflorescence is fastigiated with the lateral peduncles perpendicular to the rachis, and it was not observed any other species of Alcantarea along the type locality that could be the second parental lineage. Populations of A. trepida are well established with thousands of individuals not only at Baixo Guandu, but also $120 \mathrm{~km}$ north at Nova Venécia. 
Table 1 - Morphological comparison of Alcantarea trepida and its closest relatives.

\begin{tabular}{|c|c|c|c|c|}
\hline Feature & Alcantarea extensa & Alcantarea simplicisticha & Alcantarea trepida & Alcantarea vinicolor \\
\hline Plant height (m) & Up to 3 & Up to 2.4 & Up to 4 & Up to 2.1 \\
\hline Stem & Short & Short & $\begin{array}{l}\text { Developed, sometimes } \\
\text { sprawling }\end{array}$ & Short \\
\hline $\begin{array}{l}\text { Leaf blade } \\
\text { (width in } \mathrm{cm} \text { ) }\end{array}$ & $5-12$ & $6-7$ & $9-11$ & $6-10$ \\
\hline Leaf texture & Coriaceous & Chartaceous & Coriaceous & Coriaceous \\
\hline $\begin{array}{l}\text { Peduncle bracts } \\
\text { size (middle and } \\
\text { distal ones) }\end{array}$ & $3.5-5 \times 3-4 \mathrm{~cm}$ & $5 \times 3 \mathrm{~cm}$ & $4.5-10 \times 3-6 \mathrm{~cm}$ & $5-7 \times 2.5-4 \mathrm{~cm}$ \\
\hline $\begin{array}{l}\text { Peduncle bracts } \\
\text { position (middle } \\
\text { and distal ones) }\end{array}$ & Suberect to arcuate & Erect & Suberect & Suberect-patent \\
\hline $\begin{array}{l}\text { Base of peduncle } \\
\text { bract (shape) }\end{array}$ & $\begin{array}{l}\text { Inflated and impounding } \\
\text { water }\end{array}$ & $\begin{array}{l}\text { Not inflated and not } \\
\text { impounding water }\end{array}$ & $\begin{array}{l}\text { Inflated and } \\
\text { impounding water }\end{array}$ & $\begin{array}{l}\text { Inflated and } \\
\text { impounding water }\end{array}$ \\
\hline $\begin{array}{l}\text { Peduncle } \\
\text { (diameter in } \mathrm{cm})\end{array}$ & $1.8-3$ & $1-1.3$ & $2.5-3$ & $1.5-2.5$ \\
\hline Inflorescence & $\begin{array}{l}\text { Compound, rarely } \\
\text { simple }\end{array}$ & Simple & $\begin{array}{l}\text { Compound, rarely } \\
\text { simple }\end{array}$ & Compound \\
\hline $\begin{array}{l}\text { Inflorescence } \\
\text { branches } \\
\text { arrangement }\end{array}$ & Laxly arranged & Single branch (spike) & Subdensely arranged & Laxly arranged \\
\hline $\begin{array}{l}\text { Inflorescence } \\
\text { branches position }\end{array}$ & suberect or patent & suberect and arcuate & erect & arcuate \\
\hline Rachilla & Geniculate & Flexous to geniculate & $\begin{array}{l}\text { Straitght, if geniculate } \\
\text { only at the terminal } \\
\text { portions of branches }\end{array}$ & Geniculate \\
\hline $\begin{array}{l}\text { Rachilla internodes } \\
\text { (diameter in } \mathrm{cm})\end{array}$ & $0.6-0.7$ & $0.4-0.6$ & $1-1.6$ & $0.4-0.6$ \\
\hline $\begin{array}{l}\text { Number of flowers } \\
\text { per branch }\end{array}$ & $12-26$ & $30-40$ & $8-70$ & $8-16$ \\
\hline $\begin{array}{l}\text { Floral bracts } \\
\text { size }(\mathrm{mm})\end{array}$ & $36-42 \times 38-46$ & $40-46 \times 32-40$ & $38-48 \times 38-55$ & $20-32 \times 22-35$ \\
\hline
\end{tabular}

Paratypes: BRASIL. ESPÍRITO SANTO: Baixo Guandu, inselberg em pastagem, 19²9'26.8'S 4050'37.4”'W, 592 ms.m., 27.I.2007, fr., fl., L. M. Versieux \& A. M. Calvente 394, 395 (SP); Nova Venécia, APA Pedra do Elefante, 18.II.2008, fl., R. C. Forzza et al. 5072 (RB); Ibidem, APA Pedra do Elefante, Serra de Baixo, Pedra do Elefante, 19.II.2008, fl., C. N. Fraga et al. 1920 (RB); Ibidem, beira da rodovia Nova Venécia - São Gabriel da Palha, propriedade do Sr. Valdemar, 9.V.2008, fl., fr., A. P. Fontana et al. 5241 (RB).

Distribution, ecology and conservation: Alcantarea trepida is a heliophyte, occuring between $300-900$ ms.m. on steep rocky walls and also on inselberg plateaus at the municipalities of Baixo Guandu, in the central western region and also at Nova Venécia, $120 \mathrm{~km}$ further north in Espírito Santo State. The species is not threatened by extinction because it occurs within the Environmental Protection Area of Pedra do Elefante. Additionally, populations tend to present high densities of individuals (Fig. 3g) growing on hardly accessible places, as is the case in the type locality (Fig. 3a). Bees frequently eat petals and stamens and nests of Hemiptera sometimes can be seen underneath the primary bracts. Scars caused by these insects can also be seen as brownish protuberances along the lateral peduncles. If these injuries are caused by the Hemiptera phytophagy or by galling activity is still to be investigated. At the type specimen population several capsules were bearing germinated seeds inside (Fig. 3f) characterizing a case of viviparity. Phenology: Blooming from December to May. Immature fruit collected in May, and old capsules with seeds germinating inside collected in January. Etymology: From Latin, Trepidus, a, um means in fright, scared. The specific epithet trepida was chosen here as metaphoric insinuation to the erect branches of the inflorescence that remain upright even after fructification, in a "scared" position. 


\section{Acknowledgements}

We thank Dr. Rafaela Forzza, curator of RB for donating duplicate collections to SP. Claudio Nicoletti Fraga provided photographs and information about the Nova Venécia population. Natascha Wagner translated German texts and Alice Calvente helped during fieldwork and allowed the use of one picture. Lynn Parker, from Kew, provided the pictures of Morren's Icon. This work is part of the Ph. D. thesis of the first author conducted in the University of São Paulo. Financial support was provided by FAPESP to the first author and by CNPq to the senior author. We are also grateful to Dr. Tarciso Filgueiras for checking the Latin diagnosis, Derek Butcher and Mark Paul for linguistic advice and to two anonymous referees for their constructive comments.

\section{Literature cited}

Barbará, T.; Martinelli, G.; Fay, M.F.; Mayo, S.J. \& Lexer, C. 2007. Population differentiation and species cohesion in two closely related plants adapted to neotropical high-altitude 'inselbergs', Alcantarea imperialis and Alcantarea geniculata (Bromeliaceae). Molecular Ecology 16: 1981-1992.

Barbará, T.; Lexer, C.; Martinelli, G.; Mayo, S.J.; Fay, M.F. \& Heuertz, M. 2008. Within-population spatial genetic structure in four naturally fragmented species of a neotropical inselbergs radiation, Alcantarea imperialis, A. geniculata, A. glaziouana and A. regina (Bromeliaceae). Heredity 101: 285-296.

Barbará, T.; Martinelli, G.; Palma-Silva, C.; Fay, M. F.; Mayo, S. \& Lexer, C. 2009. Genetic relationships and variation in reproductive strategies in four closely related bromeliads adapted to neotropical 'inselbergs': Alcantarea glaziouana, A. regina, A. geniculata and A. imperialis (Bromeliaceae). Annals of Botany 103: 65-77.

Grant, J.R. 1995. The resurrection of Alcantarea. Tropische und subtropische Pflanzenwelt 91: 7-15.

Leme, E.M.C. \& Paula, C.C. 2008. Two new Alcantarea species from Minas Gerais. Journal of the Bromeliad Society 58: 5-11.

Leme, E. M.C.; Fraga, C.N.; Kollmann, L.J.C. \& Fontana, A.P. 2008. Three new Alcantarea species from Espírito Santo and Minas Gerais, Brazil. Journal of the Bromeliad Society 58: 205-216.

Leme, E.M.C. 2009. Alcantarea mucilaginosa a new species from Espírito Santo, Brazil. Journal of the Bromeliad Society 59: 12-15.

Pereira, E. 1974. Species Novae in Brasilia Bromeliacearum - VI. Bradea 1: 383-387.

Smith. L.B. 1943. Bromeliáceas novas ou interessantes do Brasil - II. Arquivos de Botânica do Estado de São Paulo 1: 102-122, tab. 101-134.

Smith, L.B. \& Downs, R.J. 1977. Tillandsioideae (Bromeliaceae). Flora Neotropica Monograph 14: 663-1492.

Versieux, L. M. \& Wanderley, M. G. L. 2007a. Alcantarea (E. Morren ex Mez) Harms. In: Wanderley, M. G. L.; Shepherd, G. J.; Melhem, T. S. \& Giulietti, A. M. (eds). Flora fanerogâmica do estado de São Paulo. Instituto de Botânica, São Paulo. Vol. 5. Pp. 59-62.

Versieux, L. M. \& Wanderley, M. G. L. 2007b. Two new species of Alcantarea (Bromeliaceae, Tillandsioideae) from Brazil. Brittonia 59: 57-64.

Versieux, L. M. \& Wendt, T. 2006. Checklist of Bromeliaceae of Minas Gerais, Brazil, with notes on taxonomy and endemism. Selbyana 27: 107-146

Wittmack, L. 1891. Vriesea regina Beer. Gartenflora 40: 160-163. 